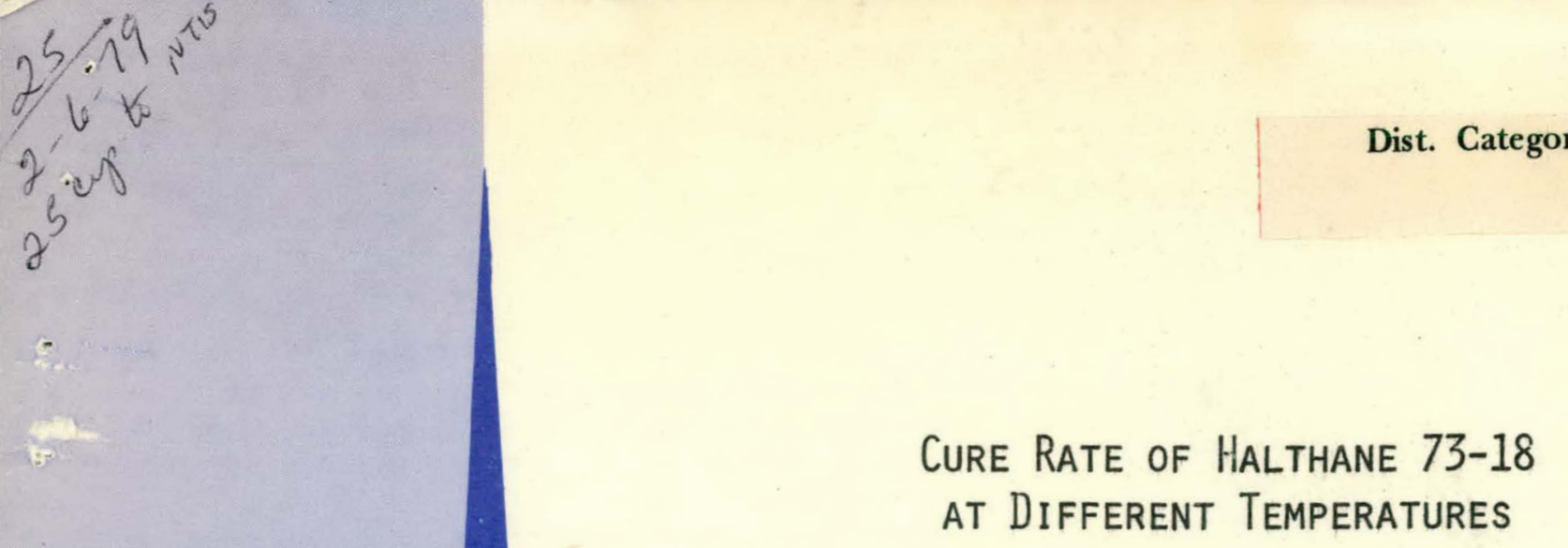

MHSMP- 77- 65

at Different Temperatures

Patricia A. Foster

Rabert W. Ashcraft

DEVELOPMENT DIVISION

DECEMBER 1977

Process Development

Endeavor No. 101
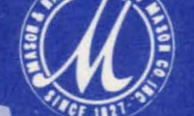

(1)

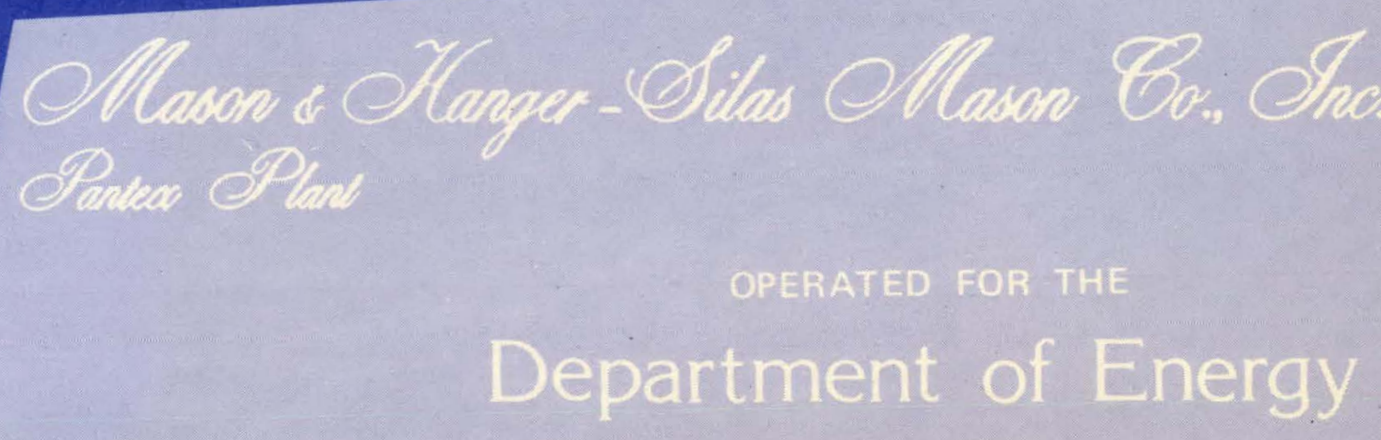




\section{DISCLAIMER}

This report was prepared as an account of work sponsored by an agency of the United States Government. Neither the United States Government nor any agency Thereof, nor any of their employees, makes any warranty, express or implied, or assumes any legal liability or responsibility for the accuracy, completeness, or usefulness of any information, apparatus, product, or process disclosed, or represents that its use would not infringe privately owned rights. Reference herein to any specific commercial product, process, or service by trade name, trademark, manufacturer, or otherwise does not necessarily constitute or imply its endorsement, recommendation, or favoring by the United States Government or any agency thereof. The views and opinions of authors expressed herein do not necessarily state or reflect those of the United States Government or any agency thereof. 


\section{DISCLAIMER}

Portions of this document may be illegible in electronic image products. Images are produced from the best available original document. 


\section{NOTICE}

This report was prepared as an account of work sponsored by the United States Government. Neither the United States nor the United States Department of Energy, nor their employees, nor any of their contractors, subcontractors, or their employees, makes any warrany, express or implied, or assumes any legal liability or responsibility for the accuracy, completeness or usefulness of any information, apparatus, product or process disclosed, or represents that its use would not infringe privately-owned rights.

Printed in the United States of America

Available from

National Technical Information Service

U. S. Department of Commerce

5285 Port Royal Road

Springfield, VA 22161

Price: Printed Copy $\$ 4.00$; Microfiche $\$ 3.00$ 


\title{
CURE RATE OF HALTHANE 73-IB AT DIFFERENT TEMPERATURES
}

\author{
Patricia A. Foster \\ Robert W. Asheraft \\ DEVELOPMENT DIVISION \\ Process Development \\ Endeavor No. 101
}

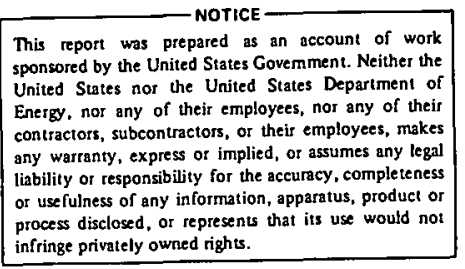

\begin{abstract}
Halthane 73-18 is a new polyurethane type adhesive being developed for an assembly operation. This report includes the cure rate at ambient, 38,78 and $100 \mathrm{C}$. An equation relating cure rate, time and temperature is established.
\end{abstract}

\section{DISCUSSION}

The Halthane series of polyurethane adhesives synthesized by Lawrence Livermore Laboratories(1) are being studied for application to Pantex assembly processes. The series consisted of three each two-part systems designated 73-14, 73-18, and 87-1. In addition to the Halthane series, several others were investigated. but the adhesive chosen for development was Halthane 73-18. The requirement for a new adhesive resulted from (1) the toxicity of the Adiprene L-100 and L-167 curing agent, MOCA, (2) the variations in mechanical properties of L-315/polyol over the required temperature range, and (3) the high viscosity and short working time of the DuPont 520/MDA system(2).

Halthane 73-18 consists of two components, the resin prepolymer and the hardner which are designated $\mathrm{T}$ and $\mathrm{R}$; respectively. The prepolymer consists of the reaction product of 3.5 moles of MDI [4,4-methylene bis (phenylisocyanate)] and 1.0 mole of polytetramethylene ether glycol (Polymeg). The hardener contains a mixture of $85 \%$ Polymeg 1000, 10\% 1,4-butanediol and $5 \% \mathrm{~N}, \mathrm{~N}, \mathrm{~N}, \mathrm{~N}$-tetrakis (2-hydroxypropyl) ethylenediane (Quadrol)(1).

The rate of cure for thin films of the Halthane 73-18 (66 weight percent component $\mathrm{T}$ and 34 weight percent component $R$ ) was studied by following the decrease in the absorbance of the $4.35 \mu \mathrm{m}$ band in the infrared spectral region. This band was attributed to the isocyanate functional group. A Beckman IR-12 ${ }^{a}$ infrared spectrometer fitted with a RIIC ${ }^{b}$ hot stage attachment was used to monitor the loss of absurbance. Fig. 1 shows the absorbance at ambient, 38,78, and $100 \mathrm{C}$.

$a_{\text {Beckman }}$ Instmuments, Inc., Fulzerton, California.

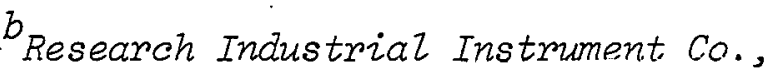
London, England. 


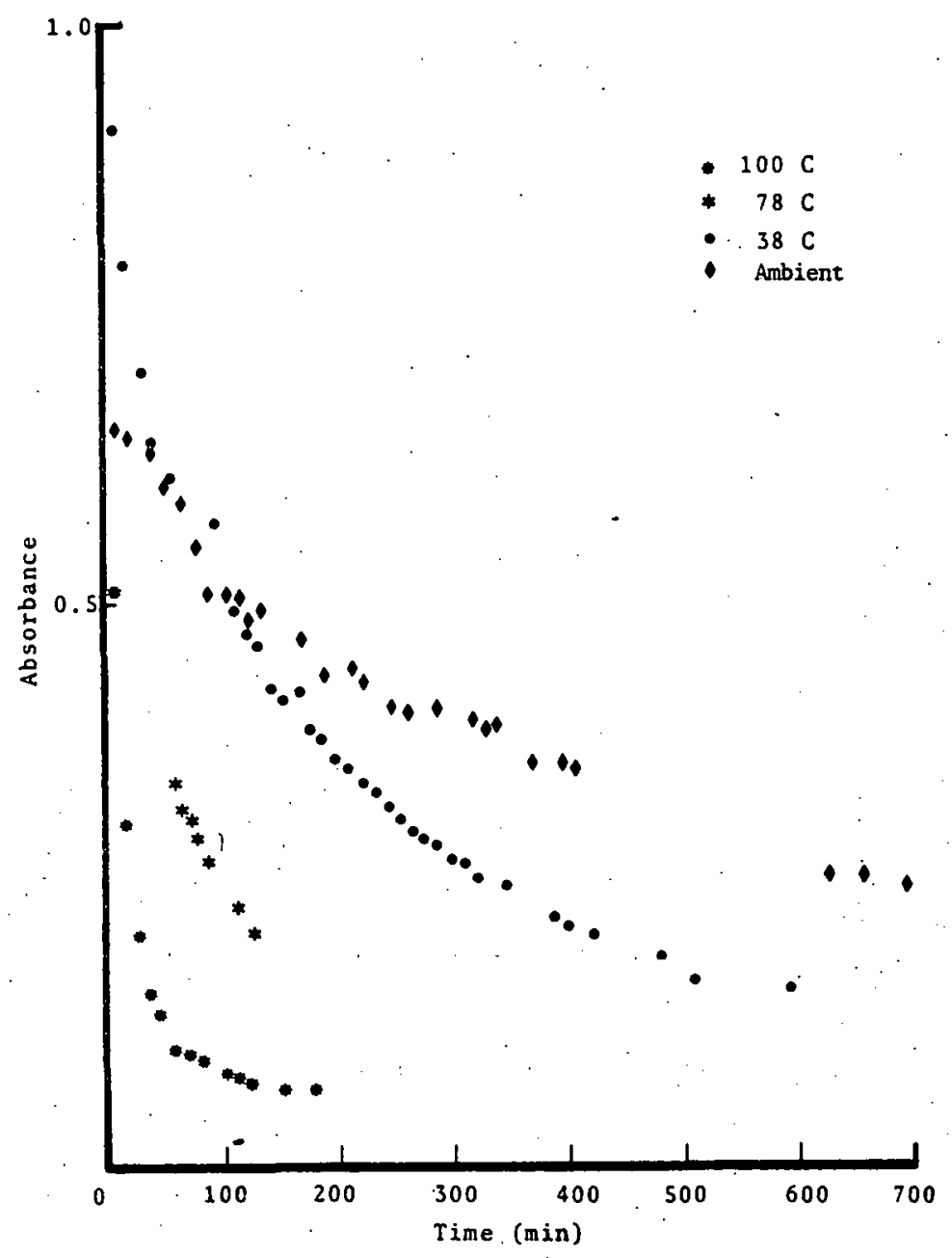

Fig. 1. Halthane 73-18 Cure Rates

The absorbance was assumed to obey the differential equation

$$
\frac{\mathrm{da}}{\mathrm{dt}}=-\mathrm{ka} \mathrm{a}^{\mathrm{n}}, \mathrm{a}(0)=1
$$

where $a$ is the absorbance, $t$ is time, $\mathrm{k}$ is the rate constant, and $\mathrm{n}$ is the reaction order. If the order is neither zero nor one, the solution to the equation is

$\ln a=\frac{1}{1-n}$ ln $[(n-1) k t+1]$

Nonlinear regression was used to fit this model to the absorbance time data for four different temperatures.

The resulting least squares estimates of the orders and rates are given below.

Temperature (C)

Ambient

38

78

100

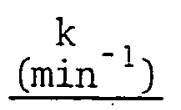

0.01336

0.00980

0.03496

0.19077 n 
As seen in Figs. 2,3 and 4 the curve fits for the 38,78 and $100 \mathrm{C}$ data are satisfactory. The model failed to provide a satisfactory fit to the ambient data and the results of this fit were not used for further analysis, The failure of the model to fit the ambient data was probably due to the amount of scatter observed in these data. This scatter could be induced by temperature variation ${ }^{c}$, moisture, and sensitivity of the instrument. The effects of these factors are less pronounced at elevated temperatures.

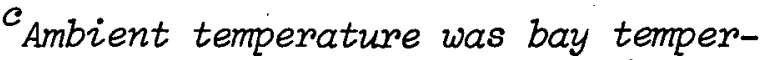
ature which could have varied over a $10 \mathrm{C}$ range.

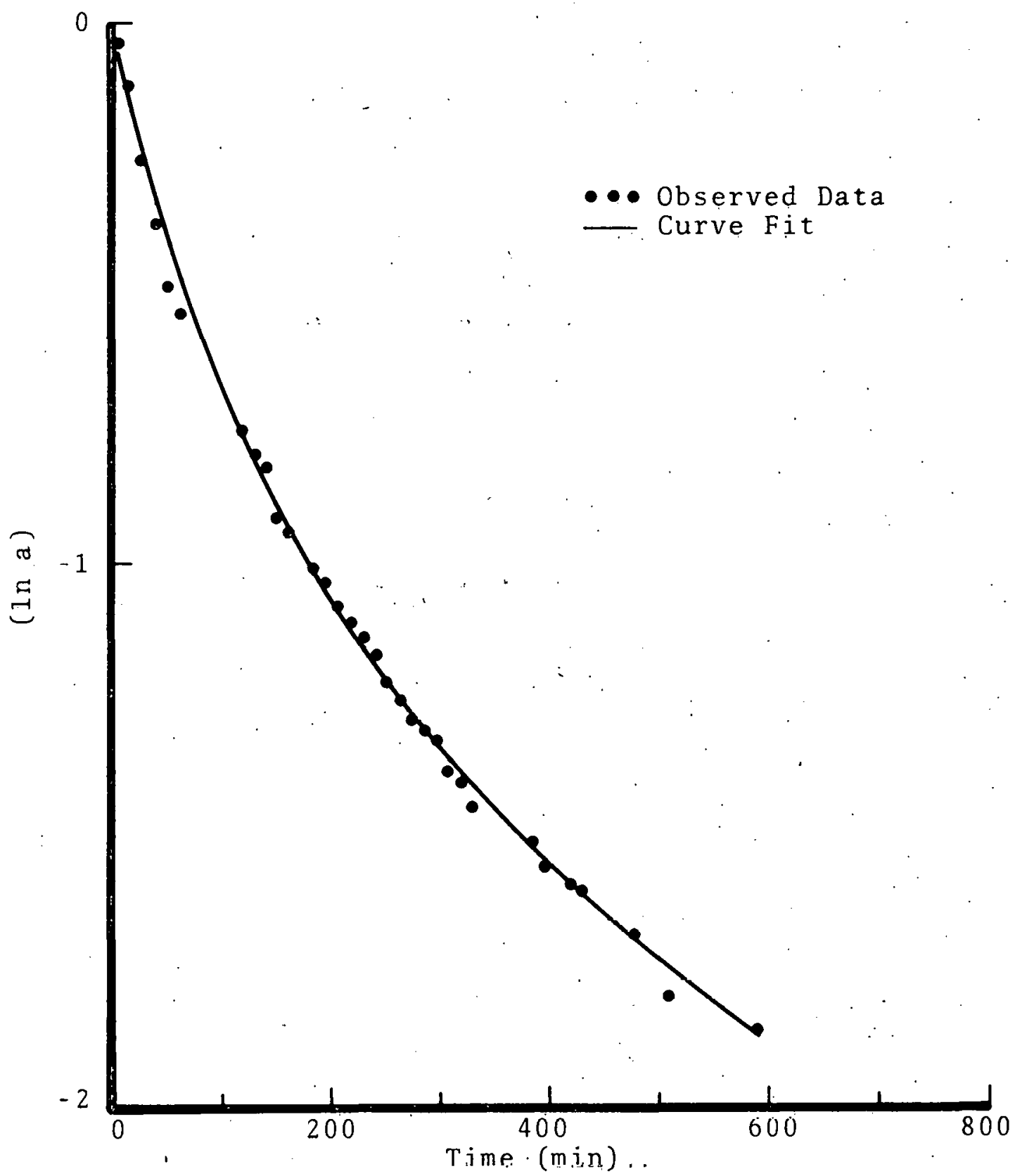

Fig. 2. In a (Absorbance) Versus Time for the Cure Rate at $38 \mathrm{C}$ 


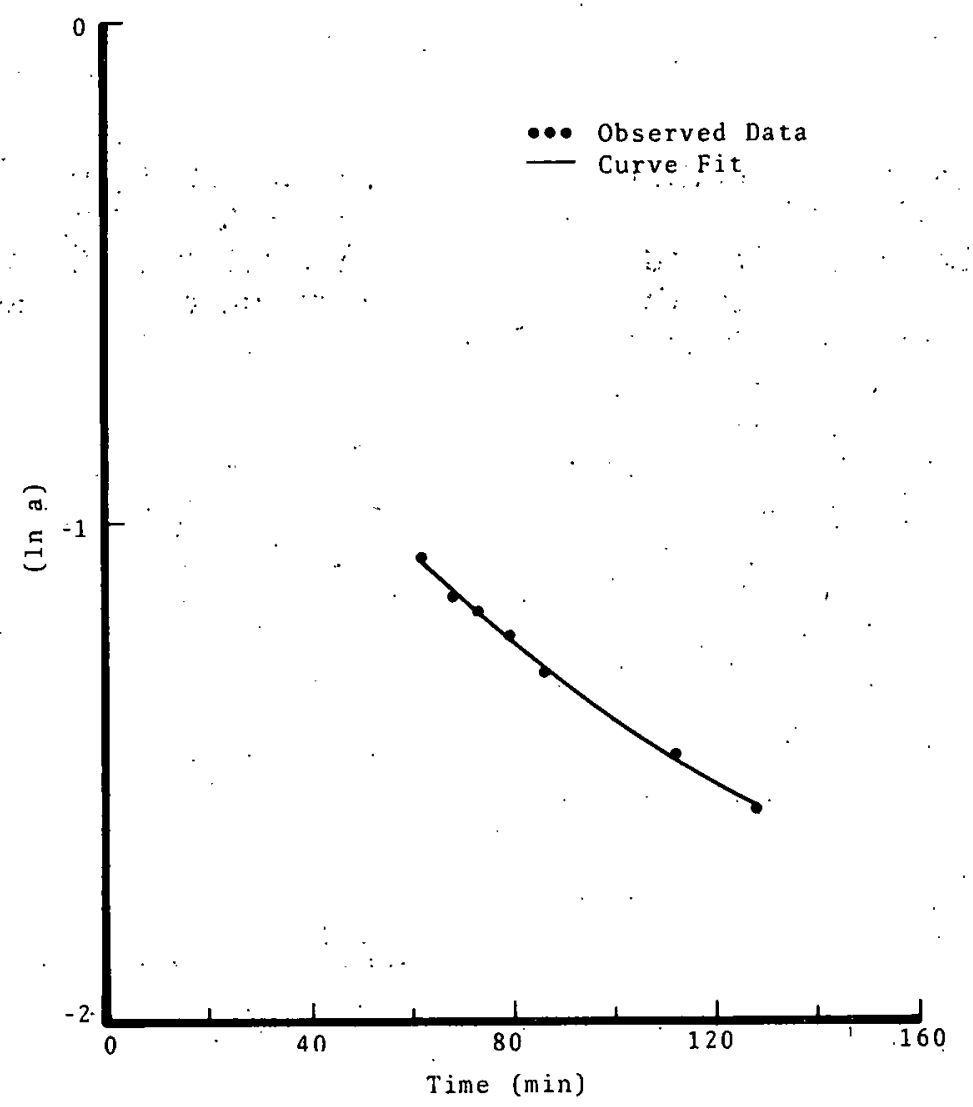

Fig. 3. In a (Absorbance) Versus Time for the Cure Rate at $78 \mathrm{C}$

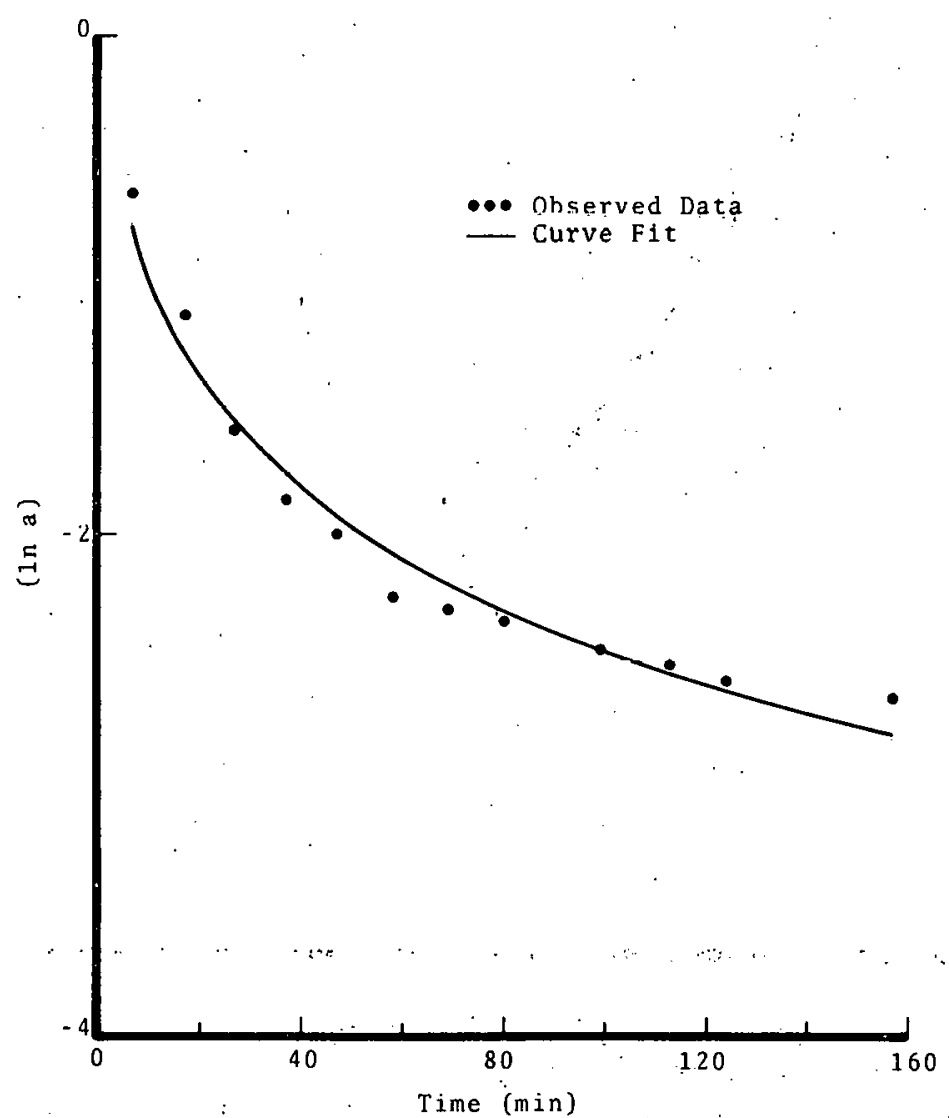

Fig. 4. In a (Absorbance) Versus Time for the Cure Rate at $1.00 \mathrm{C}$ 
In order to utilize equation (2) it was necessary to express $n$ and $k$ as functions of temperature. The rate (k). is usually assumed to have an Arrhenius temperature dependence given by

$$
k=A e^{-E / R T}
$$

where $A$ is the collision frequency, $E$ is the activation energy, and $R$ is the gas constant. As seen in Fig. 5, in $\mathrm{k}$ is not sufficiently linear in $1 / \mathrm{T}$ to support this assumption, so an empirical model was used instead of the Arrhenius equation. An empirical model was also used to obtain $\mathrm{n}$ as a function of temperature. The model chosen for $\mathrm{n}$ and $\mathrm{k}$ was a modified exponential in temperature of the form

$$
n(\text { or } k)=A_{1}+e^{A_{2}+A_{3} T}
$$

where $A_{1}, A_{2}$, and $A_{3}$ are the curve fit parameters and $T$ is the temperature. This model passes through each of the three temperature points, is sufficiently smooth for interpolation purposes, and is we11-behaved outside the range of the data points. Figs. 6 and 7 are plots of the rate and order as functions of temperature; these figures also show the curve fits of equation (4) to the experimental results.

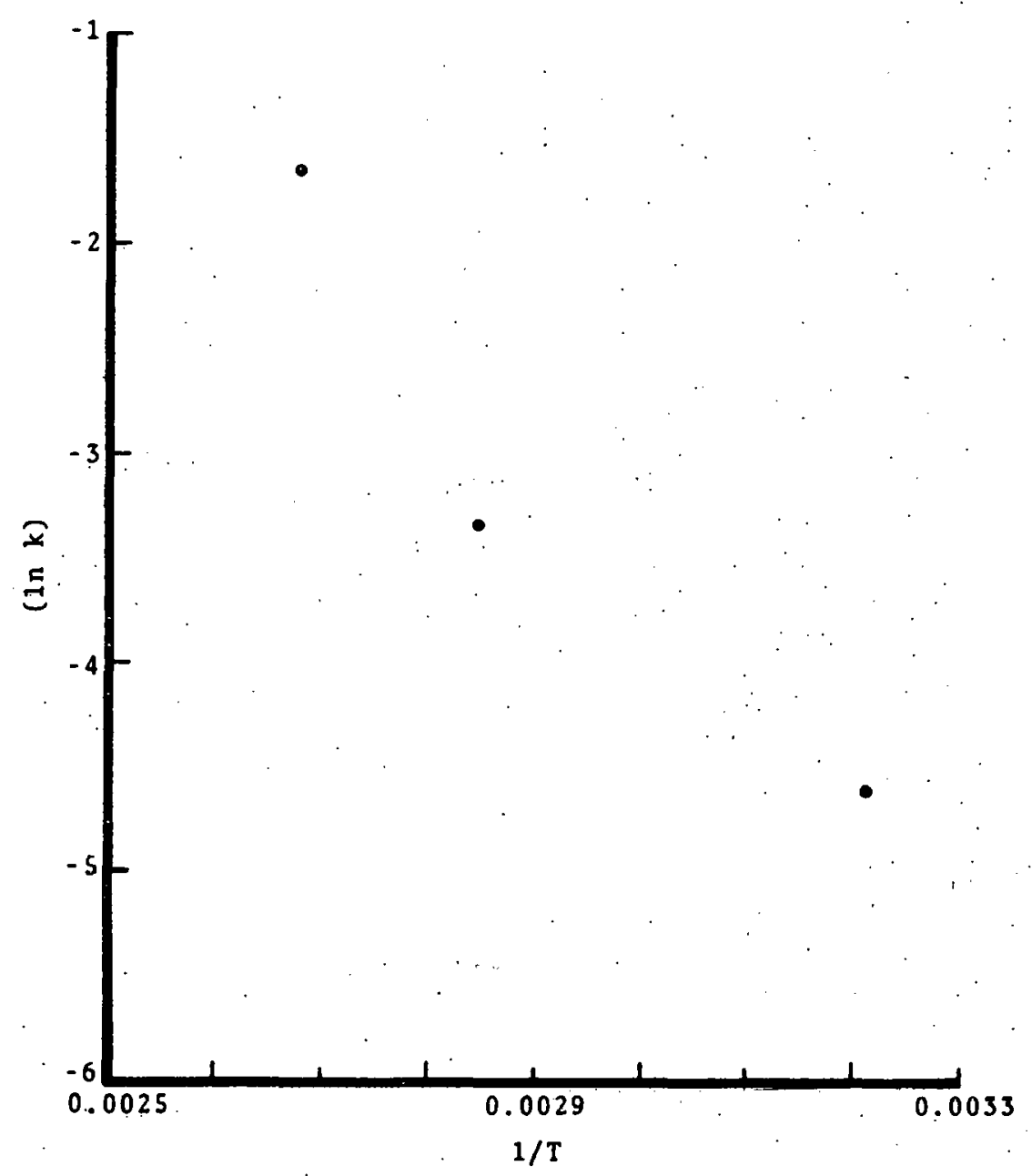

Fig. 5. In $\mathrm{k}$ Versus $1 / \mathrm{T}$ for the Cure Rate of 100,78 , and $38 \mathrm{C}$ 


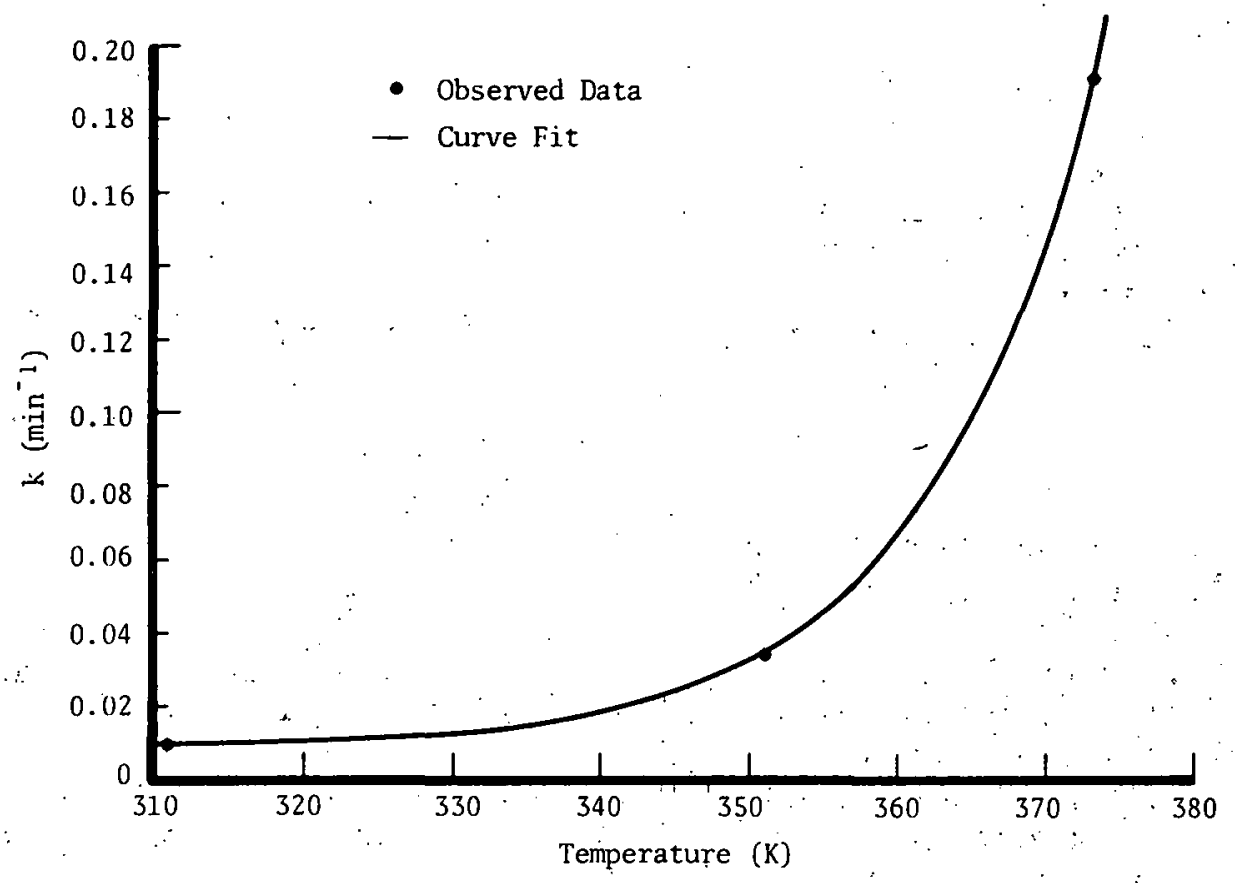

Fig. 6. Least Squares Estimates of Rate Versus Temperature

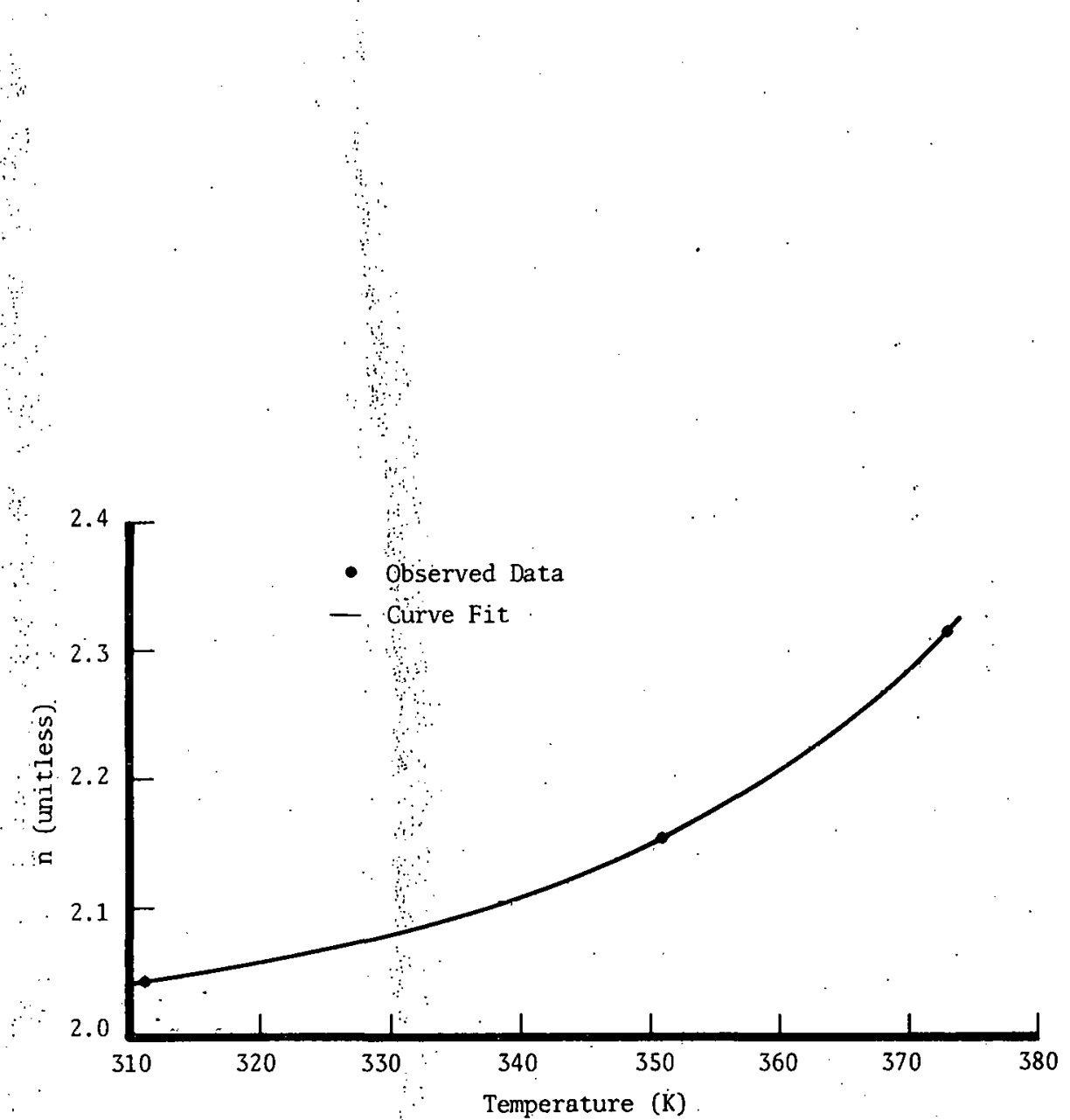

Fig. 7. Least Squares Estimates of Reaction Order Versus Temperature 
The cure rate $(\mathrm{C})$ is related to absorbance by

$$
C=1-a
$$

so equation (2) can be used to relate cure rate to time and temperature. Equation (2) can be expressed as

$$
a=[(n-1) k t+1]^{1 / 1-n}
$$

and by using equation (5), the expression for cure rate is

$$
C=1-[(n-1) k t+1]^{1 / 1-n}
$$

where $k=A_{1}+e^{A_{2}+A_{3} T}$

$$
\begin{aligned}
& A_{1}=0.009049 \\
& A_{2}=-34.7296 \\
& A_{3}=0.08854
\end{aligned}
$$

and $n=B_{1}+e^{B_{2}+B_{3} T}$

$$
\begin{array}{lr}
B_{1}= & 1.9994 \\
B_{2}= & -13.1775 \\
B_{3}= & 0.03224
\end{array}
$$

Equation (7) can be rearranged to give time as a function of cure rate and temperature:

$$
t=\frac{(1-C)^{1-n}-1}{(n-1) k}
$$

Solving equation (7) for temperature is

\begin{tabular}{|c|c|c|c|c|c|}
\hline & $\begin{array}{l}\text { Component } \\
\text { (g) }\end{array}$ & & $\begin{array}{l}\text { Cure Time } \\
\quad(\mathrm{hr})\end{array}$ & & $\begin{array}{l}\text { Shore } A^{*} \\
\text { Hardness }\end{array}$ \\
\hline $\begin{array}{l}\mathrm{T} \text {-Component } \\
\mathrm{R} \text {-Component }\end{array}$ & $\begin{array}{l}7.0 \\
3.0\end{array}$ & . & $\begin{array}{l}23.50 \\
29.00 \\
29.33 \\
46.00 \\
70.67\end{array}$ & & $\begin{array}{l}36 / 36 \\
42 / 42 \\
45 / 45 \\
51 / 51 \\
55 / 55\end{array}$ \\
\hline $\begin{array}{l}\mathrm{T} \text {-Component } \\
\mathrm{R} \text {-Component }\end{array}$ & $\begin{array}{l}6.6 \\
3.4\end{array}$ & & $\begin{array}{l}23.67 \\
29.25 \\
29.50 \\
46.25 \\
71.83\end{array}$ & & $\begin{array}{l}48 / 48 \\
56 / 55 \\
55 / 55 \\
60 / 60 \\
63 / 63\end{array}$ \\
\hline $\begin{array}{l}\text { T-Component. } \\
\text { R-Component } \\
\text { DABCO }\end{array}$ & $\begin{array}{l}6.6 \\
3.4 \\
0.02\end{array}$ & & $\begin{array}{r}6.00 \\
23.92 \\
29.42 \\
29.75 \\
46.77 \\
71.08\end{array}$ & 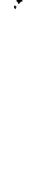 & $\begin{array}{l}32 / 20 \\
47 / 45 \\
47 / 47 \\
47 / 47 \\
47 / 45 \\
47 / 47\end{array}$ \\
\hline
\end{tabular}
not practical.

Table I gives the Shore A hardness for the Halthane 73-18 using different ratios of the components. DABCO was incorporated into the composition but did not appear to increase the cure rate.

Table I. Cure Times at Ambient Temperature of Different Ratios of the Halthane 73-18 
CONCLUSION

The rates of cure for Hal thane 73-18 (66\% component $\mathrm{T}$ and $34 \%$ component $\mathrm{R}$ ) were determined at ambient, 38,78 and $100 \mathrm{C}$. An equation was established relating cure rate, temperature and time.

\section{REFERENCES}

1. L. P. Althouse and H. G. Harmon, Development of Halthane Adhesives for Phase III weapons, UCID-16990.

2. L. P. Althouse and H. G. Hanmon, Halthane Adhesives for Phase III Weapons, Status Report No. 2, UCID-17348. 
DOE

Ralph E. Caudle

Assistant Director of Operations

Military Application

Attn: Robert E. Clough

Washington, DC

$\underline{\text { ALO }}$

H. N. Meyer, Director

Weapons Development Division

R. R. Fredlund, Jr., Director

Classification \& Technical Information

$\underline{\mathrm{AAO}}$

P. M. Ramey, Chief, Operations Branch

Mound Facility

R. T. Braun

SLL

R. D. Cozine - Org. 8180

$\underline{\text { LLL }}$

G. L. Dittman (10 Copies)

Attn: A. C. Van Dyk

C. T. Brockett

Technical Information Dept.

LASL

E. H. Eyster - WX-DO

Attn: J. J. Wechsler

R. N. Rogers - $W X-2$

J. Aragon - WX-3

Report Library - ISD-4
SLA

B. E. Arthur - Org. 1570

J. C. Crawford - Org. 2500/

D. H. Anderson - Org. 2510

J. C. King - Org. 2300/

C. B. McCampbe11 - Org. 2310

Central Technical Files - Org. 3141

$\underline{\text { TIC }}$

Technical Information Center (27 Copies)

Oak Ridge, TN

$\underline{\mathrm{UK}}$

Jack Kirkham

Atomic Weapons Research Establishment

Aldermaston, Reading, England

$\underline{\text { PX }}$

Division Manager, Mfg. Engineering

Division Manager, Quality

Division Manager, Development

Division Manager, Manufacturing

Division Manager, Safety \& Fire

Protection

Education \& Training Center (5 Copies)

Technical Library (5 Copies)

Circulation Copy:

(1) Asst. Plant Manager

(2) Plant Manager

(3) M\&H-SM Co., Inc., Lexington, $\mathrm{KY}$ 